\title{
A functional assessment of patients two years after lung transplantation in Poland
}

\author{
Dariusz T. Jastrzębski ${ }^{1}$, Anna Gumola ${ }^{1}$, Jacek Wojarski², Sławomir Żegleñ², Marek Ochman², \\ Damian Czyżewski ${ }^{3}$, Dariusz Ziora ${ }^{1}$, Marian Zembala ${ }^{2}$, Jerzy Kozielski ${ }^{1}$ \\ ${ }^{1}$ Department of Lung Diseases and Tuberculosis, Medical University of Silesia, Zabrze, Poland \\ ${ }^{2}$ Department of Cardiac Surgery and Transplantation, Medical University of Silesia, Silesian Center \\ for Heart Diseases, Zabrze, Poland \\ ${ }^{3}$ Department of Thoracic Surgery, Medical University of Silesia, Zabrze, Poland
}

Kardiochirurgia i Torakochirurgia Polska 2014; 11 (2): 162-168

\begin{abstract}
The aim of the study was to assess the long-term results of lung transplantation (LT) in Poland two years after the procedure.

Material and methods: The study included patients who underwent LT between December 2004 and December 2009 in the Silesian Center for Heart Diseases in Zabrze. Various lung functions (forced vital capacity - FVC; forced expiratory volume in 1 second - FEV ${ }_{1}$ ), the quality of life (SF-36 questionnaire), the level of perceived dyspnea (Medical Research Council MRC; basic dyspnea index - BDI), and the patient's mobility (the 6-minute walking test-6MWT) were assessed before and approximately 24 months after LT. Among 35 patients who underwent LT, 20 patients were referred to our study (mean age: $46.6 \pm 9.03$ years).

Results: After LT, a statistically significant increase was observed in the distance achieved in the 6MWT (323.8 vs. $505.8 \mathrm{~m}$ ), FVC (1.64 vs. $2.88 \mathrm{~L}$ ), and FEV (1.37 vs. $2.09 \mathrm{~L})$. An improvement in perceived dyspnea in MRC and BDI questionnaires was observed in patients with chronic obstructive pulmonary disease (COPD) after LT. The assessment of the quality of life, excluding perceived pain, showed the most significant improvement in the physical cumulative score (PCS; 25 vs. 45 points), especially in patients with idiopathic pulmonary fibrosis.

Conclusions: Lung transplantation in Poland, in patients who live longer than 2 years after the procedure, significantly improves the mobility, lung function, perceived dyspnea, and the quality of life.
\end{abstract}

Key words: dyspnea, lung function tests, lung transplantation.

\section{Introduction}

The first single lung transplantation was performed in the Silesian Center for Heart Diseases in Poland in April 2004 [1]. Since that time, lung transplantations (LTs) have

\section{Streszczenie}

Cel pracy: Odległa ocena efektu transplantacji płuc (lung transplantation - LT) po 2 latach od wykonanego zabiegu.

Materiat i metody: Badaniem objęto chorych, u których w okresie grudzień 2004 r. - grudzień 2009 r. (5 lat) wykonano zabieg LT w Śląskim Centrum Chorób Serca (SCCS) w Zabrzu. W trakcie kwalifikacji oceniono czynność płuc (FVC, FEV ${ }_{1}$, $\mathrm{FEV}_{1} \% \mathrm{VC}$ ), jakość życia (kwestionariusz SF-36), poziom odczuwanej duszności (testy MRC, OCD, BDI) i mobilność [test 6-minutowego chodu (6 MWT)]. W ciągu 24 miesięcy ( \pm 2 miesiące) po przeszczepie u biorców płuca badania powtórzono. Z 35 chorych, u których wykonano w tym okresie LT, do badania zakwalifikowano 20 chorych (średnia wieku 46,6 \pm 9,03 roku).

Wyniki: Po przeszczepie stwierdzono istotne statystycznie przyrosty: dystansu 6 MWT z 323,8 m do 505,8 m, FVC (1,64 vs 2,88 l) i $\mathrm{FEV}_{1}$ (1,37 vs 2,09 l). Największą poprawę w odczuwaniu duszności wykazaną w kwestionariuszu MRC, OCD i BDI stwierdzono u chorych z przewlekłą obturacyjną chorobą płuc (POChP), po LT. Ocena jakości życia wykazała poprawę w kwestionariuszu SF-36, największą w skumulowanej ocenie zdrowia fizycznego (PCS; 25 vs 45 pkt), szczególnie u chorych z idiopatycznym włóknieniem płuc.

Wnioski: Transplantacja płuca w Polsce u chorych, którzy przeżyli 2 lata od zabiegu, jest procedurą w sposób istotny poprawiającą mobilność, czynność układu oddechowego, odczuwanie duszności oraz postrzeganie jakości życia.

Słowa kluczowe: duszność, czynność płuc, przeszczep płuc.

been performed routinely in Poland, offering patients with end-stage pulmonary disease a viable option of survival. The Silesian Center for Heart Diseases has so far been the only medical center in Poland where lung transplantations

Address for correspondence: Dariusz T. Jastrzębski, MD, PhD, Department of Lung Diseases and Tuberculosis, Medical University of Silesia, Zabrze, Poland, Koziołka 1, 41-803 Zabrze, Poland, tel. +48502038138, fax +482745664, e-mail: darekjdr@poczta.onet.pl 
are performed. Presently, more than 15 LTs are performed annually in Poland. Patients have been referred to the Department for Lung Diseases and Tuberculosis in Zabrze, Poland for LT since 1999. In the present study, we have analyzed the effectiveness of LT in all patients who were qualified for the procedure between the years 2004-2009 in the Department of Lung Diseases and Tuberculosis and who underwent the operation at the Silesian Center for Heart Diseases.

The aim of this study was to determine the results of LT two years after the operation. Hence, we assessed the respiratory function, mobility, quality of life, and level of dyspnea in all patients and compared the results with those from before the operation.

\section{Material and methods}

The study included all patients who underwent lung transplantation between December 2004 and December 2009 at the Silesian Center for Heart Diseases in Zabrze. During that time, 35 operations were performed (including 1 re-transplantation). Within this group, 12 patients (34\%) died within 1 year after the operation and 2 patients (6\%) remained in the hospital for over 6 months after the op- eration due to complications (bronchiectasis, aspergillosis). Ultimately, we included 20 patients in the study who fulfilled the assumed criteria (Table I).

The criteria of qualification for the study included:

1) LT performed in the period 2004-2009,

2) time since $L T=24$ months \pm 2 months,

3) the possibility to perform study assessments during LT follow-up visits not related to the treatment of bronchiolitis obliterans syndrome (BOS) or other LT complications,

4) hospitalization was free of complications and no longer than 6 months in one year (the total time after LT).

The first examination was performed at the time of referral for LT. We assessed the following parameters: dyspnea, the quality of life, mobility, and respiratory function.

\section{Assessment of dyspnea}

The following clinical methods were used for dyspnea assessment:

1) the modified dyspnea scale of the United Kingdom Medical Research Council (MRC),

2) the Baseline Dyspnea Index (BDI) describing dyspnea in 5 steps integrated into 3 categories: a) functional impair-

Tab. I. Demographic data, date of referral for LT, date of LT, type of operation in each patient

\begin{tabular}{|c|c|c|c|c|c|c|c|}
\hline Initials & Gender & Age & Diagnosis & Date of referral for LT & Date of LT & $\begin{array}{l}\text { No. of waiting days } \\
\text { from referral for LT }\end{array}$ & $\begin{array}{c}\text { Type } \\
\text { of operation }\end{array}$ \\
\hline E.B. & M & 54 & IPF & 10.12.2004 & 11.12.2004 & 1 & SLT \\
\hline G.J. & M & 48 & IPF & 23.05 .2005 & 17.03.2006 & 298 & SLT \\
\hline P.A. & $M$ & 31 & Emphysema & 02.11 .2006 & 26.11.2006 & 24 & DLT \\
\hline K.K. & $\mathrm{F}$ & 50 & COPD & 22.11.2006 & 06.12 .2006 & 184 & DLT \\
\hline K.A. & M & 49 & IPF & 09.03.2007 & 26.03.2007 & 16 & SLT \\
\hline G.A. & M & 47 & IPF & 19.01.2007 & 23.07.2007 & 184 & SLT \\
\hline Ś.J. & M & 61 & IPF & 03.07.2007 & 13.12.2007 & 163 & SLT \\
\hline T.A. & $M$ & 46 & ILD & 02.11 .2006 & 14.12.2007 & 407 & SLT \\
\hline D.K. & M & 36 & Pneumoconiosis & 19.17.2006 & 14.12.2007 & 513 & SLT \\
\hline Ż.E. & $\mathrm{F}$ & 28 & ILD & 19.09.2006 & 05.06 .2008 & 452 & SLT \\
\hline B.J. & $M$ & 50 & IPF & 08.01.2008 & 29.02 .2008 & 52 & SLT \\
\hline J.A. & $M$ & 48 & IPF & 29.04.2008 & 15.11.2008 & 200 & SLT \\
\hline C.R. & $M$ & 48 & ILD & 22.07.2008 & 05.12 .2008 & 136 & DLT \\
\hline B.M. & $M$ & 30 & Emphysema & 12.08.2008 & 06.12 .2008 & 116 & DLT \\
\hline Z.K. & M & 61 & COPD & 20.01.2009 & 16.03.2009 & 55 & SLT \\
\hline O.T. & $\mathrm{F}$ & 53 & COPD & 23.10.2008 & 02.04.2009 & 161 & SLT \\
\hline Ś.M. & M & 47 & IPF & 30.06 .2008 & 09.06.2009 & 344 & SLT \\
\hline P.B. & M & 50 & IPF & 06.08.2009 & 15.09.2009 & 40 & SLT \\
\hline M.A. & M & 45 & Bronchiectasis & 28.02.2008 & 14.10.2009 & 116 & SLT \\
\hline W.A. & M & 50 & ILD & 24.04.2007 & 06.04 .2010 & 1137 & SLT \\
\hline
\end{tabular}

LT - lung transplantation, SLT - single lung transplantation, DLT - double lung transplantation, IPF - idiopathic pulmonary fibrosis, ILD - interstitial lung disease other than IPF, COPD - chronic obstructive pulmonary disease 
ment (FI); b) magnitude of task (MT); c) magnitude of effort (ME).

The details concerning the methodological aspects of dyspnea rating and quantification using the outlined methods have previously been described [2].

\section{Assessment of quality of life}

For this analysis, we used the SF-36 (Short-Form Health Survey), which belongs to a group of tools assessing the overall quality of life and is commonly used in many health service institutions.

The SF-36 questionnaire consists of 36 questions measuring the state of physical and mental health. It allows for the description of the physical quality of life via a Physical Cumulative Score (PCS), which consists of four domains: Physical Functioning (PF), Role Physical (RP) (limitations caused by physical health), Bodily Pain (BP), and General Health $(\mathrm{GH})$. It also allows for the description of the mental quality of life via a Mental Cumulative Score (MCS), which consists of two domains: Role Emotional (RE) (limitations caused by mental health) and Mental Health (MH). The point scale is from 0 to 100 points; the higher the score in each domain, the higher the assessment of the quality of life. All study patients filled out the questionnaires on their own. The methodological rules and data analysis from the SF-36 questionnaire have been described previously [2].

\section{Mobility}

To estimate mobility, the 6-minute walking test (6MWT) was used. The test was performed according to the 2002 ATS guidelines [3]. Oxygen saturation was measured during the test. The test was performed twice on every patient within one day. For analysis, the best record from the two tests was used. The same rules were applied while performing the test after lung transplantation. The primary estimated parameter was the distance achieved during the test before and after the transplantation.

\section{Respiratory function tests}

The spirometric examination was performed using the Jaeger MasterLab (Erich-Jaeger GmbH, Wurzburg, Germany). The two parameters measured were forced vital capacity (FVC) and forced expiratory volume in 1 second $\left(\mathrm{FEV}_{1}\right)$.
The measurements were expressed as absolute values in $\mathrm{L}$ and as a percentage of predicted values. The values were normalized to reference values proposed by the European Community for Steel and Coal, and were subsequently introduced as a percentage of predicted values [4].

\section{Statistical analysis}

The statistical analysis included the calculation of mean, standard deviation, relevance level, and relevance of differences for each examined parameter, and was carried out using appropriate statistical software. Student's $t$-test was used for variables characterized by normal distribution and the nonparametric Wilcoxon test for paired samples for variables without normal distribution. The level of statistical significance was set at $p<0.05$.

\section{Results}

Twenty patients who underwent LT between December 2004 and December 2009 were examined. The demographic data, the basic diagnosis which was the reason for LT evaluation, the type of LT executed, and the time spent waiting for a transplant for each patient are presented in Table I.

The examined group consisted of 17 men and 3 women with a mean age of $46.6 \pm 9.03$ years. The youngest patient was 28 years old and the oldest was 61 years old. The mean time of waiting for the transplant was $229.9 \pm 260.5$ days, and was between 1 to 1137 days. A single-lung transplantation was the most commonly performed procedure (16 SLtx, 4DLtx) (Table II).

The lung transplantation was performed mainly on patients with idiopathic pulmonary fibrosis (IPF) (9 patients, $45 \%)$ and chronic obstructive pulmonary disease (COPD) (6 patients, 30\%). The last group included patients with chronic interstitial pneumonia with etiology other than IPF (ILD, interstitial lung diseases) (5 patients, 25\%). In this group, four patients had pulmonary fibrosis due to a chronic form of hypersensitivity pneumonitis and one patient developed pulmonary fibrosis and chronic respiratory failure in the course of silicosis. The longest waiting time for lung transplantation was observed in this group (1137 days). Patients with COPD had the shortest average waiting time of $109 \pm 61$ days. The shortest waiting time for transplantation was 1 day for a patient with IPF.

Tab. II. Type of operation in relation to demographic data, waiting time, and diagnosis

\begin{tabular}{lcccc} 
Diagnosis & No. & Age [years] & No. of waiting days for LT & Type of operation \\
Total & 20 & $46.6 \pm 9.03$ & $229.9 \pm 260.5$ & 20 \\
\hline \multirow{2}{*}{ IPF } & $17 \mathrm{M} / 3 \mathrm{~F}$ & $\min 28, \max 61$ & $\min 1, \max 1137$ & 4 DLT, 16 SLT \\
\hline COPD & 9 & $\begin{array}{c}50.4 \pm 4.5 \\
\min 47, \max 61\end{array}$ & $\begin{array}{c}144.2 \pm 124.9 \\
\min 1, \max 344\end{array}$ & 9 SLT \\
\hline \multirow{2}{*}{ ILD } & 6 & $45.0 \pm 12.4$ & $109.3 \pm 60.9$ & 3 DLT, 3 SLT \\
\hline
\end{tabular}

LT - lung transplantation, SLT - single lung transplantation, DLT - double lung transplantation, IPF - idiopathic pulmonary fibrosis, ILD - interstitial lung disease other than IPF, COPD - chronic obstructive pulmonary disease 
Tab. III. Mean values of 6MWT, lung function tests, perceived dyspnea, and the quality of life in the study population before and after LT

\begin{tabular}{|c|c|c|c|c|c|c|c|c|}
\hline & & & & Patien & ed for & & & \\
\hline & $n$ & & & & & & & $p$ \\
\hline & & Mean & SD & Mean & SD & Mean & SD & \\
\hline $6 \mathrm{MWT}$ & 18 & 323.8 & 77.2 & 505.8 & 145.7 & 181.9 & 146.6 & 0.001 \\
\hline FVC & 20 & 1.64 & 0.68 & 2.88 & 0.77 & 1.24 & 0.80 & 0.001 \\
\hline FVC\%pred. & 20 & 39.4 & 13.6 & 65.8 & 14.5 & 26.4 & 15.7 & 0.001 \\
\hline $\mathrm{FEV}_{1}$ & 20 & 1.37 & 0.81 & 2.09 & 0.59 & 0.72 & 0.81 & 0.003 \\
\hline $\mathrm{FEV}_{1} \%$ pred. & 20 & 33.1 & 15.6 & 59.1 & 14.7 & 26.0 & 18.7 & 0.001 \\
\hline $\mathrm{FEV}_{1} \% \mathrm{VC}$ & 20 & 72.5 & 17.8 & 74.1 & 11.5 & 1.6 & 21.8 & 0.644 \\
\hline MRC & 20 & 3.55 & 0.69 & 1.55 & 1.00 & -2.00 & 1.08 & 0.001 \\
\hline $\mathrm{FI} / \mathrm{BDI}$ & 16 & 0.31 & 0.60 & 2.50 & 1.21 & 2.19 & 1.28 & 0.001 \\
\hline MT/BDI & 19 & 0.74 & 0.65 & 2.84 & 1.12 & 2.11 & 1.37 & 0.001 \\
\hline ME/BDI & 18 & 0.72 & 0.57 & 3.22 & 0.88 & 2.50 & 1.04 & 0.001 \\
\hline $\mathrm{FI}+\mathrm{MT}+\mathrm{ME}$ & 20 & 1.70 & 1.53 & 7.90 & 2.83 & 6.20 & 3.16 & 0.001 \\
\hline PF & 20 & 15.1 & 11.1 & 45.0 & 10.6 & 30.0 & 14.5 & 0.001 \\
\hline RP & 20 & 20.5 & 24.7 & 42.1 & 11.7 & 21.6 & 29.1 & 0.005 \\
\hline BP & 20 & 53.1 & 30.5 & 50.2 & 12.0 & -2.9 & 29.5 & 0.911 \\
\hline GH & 20 & 25.3 & 10.6 & 45.2 & 10.1 & 19.9 & 15.9 & 0.001 \\
\hline VT & 20 & 39.8 & 15.1 & 55.9 & 11.7 & 16.1 & 18.6 & 0.001 \\
\hline SF & 20 & 34.8 & 18.5 & 46.5 & 9.8 & 11.7 & 17.9 & 0.014 \\
\hline RE & 20 & 23.6 & 24.8 & 44.4 & 15.8 & 20.8 & 26.2 & 0.003 \\
\hline $\mathrm{MH}$ & 20 & 50.0 & 17.4 & 50.3 & 10.2 & 0.2 & 17.3 & 0.601 \\
\hline PCS & 20 & 25.4 & 8.3 & 45.0 & 9.6 & 19.6 & 13.7 & 0.001 \\
\hline MCS & 20 & 39.5 & 8.5 & 50.3 & 11.4 & 10.8 & 10.5 & 0.001 \\
\hline
\end{tabular}

6MWT - 6 minute walking test, FVC - forced vital capacity, FEV - forced expiratory flow in 1 second, MRC - Medical Research Council, OCD - oxygen cost diagram, $\mathrm{BDI}$ - Baseline Dyspnea Index, FI - Functional Impairment, MT - Magnitude of Task, ME - Magnitude of Effort, PF - Physical Functioning, RP - Role Physical, BP - Bodily Pain, GH - General Health, VT - Vitality, SF - Social Functioning, RE - Role Emotional, MH - Mental Health, PCM - Physical Cumulative Score, MCS Mental Cumulative Score

\section{6-minute walking test}

Before the transplantation, the average distance achieved during the 6-minute walking test (6MWT) was $323.8 \pm 77.2 \mathrm{~m}$ (Table III), and all patients' results were below normal values; the lowest observed value was not more than $10 \mathrm{~m}$. After the transplantation, the 6MWT was not repeated for two patients. One of them (ZE) had complications including an ischemic stroke followed by paralysis of the limbs; the other patient had femoral artery embolus and, for this reason, needed a lower limb amputation. After the lung transplantation, a statistically significant increase $(p<0.0001)$ in distance was achieved, increasing from $323.8 \pm 77.2 \mathrm{~m}$ to $505.8 \pm 145.7 \mathrm{~m}$. The results of the 6MWT for each patient before and after LT are shown in Figure 1 . In 10 patients (50\%), the distance achieved in the 6MWT after LT exceeded $500 \mathrm{~m}$. A decrease in the distance achieved after LT was observed in two patients, while in the remaining group an increase in distance achieved was observed. The mean increase in the distance achieved was $181.9 \pm 146.6 \mathrm{~m}$.

The largest increase in the distance achieved in the 6MWT was observed in patients with ILD $(526 \mathrm{~m})$, and the smallest in patients with IPF (82 m).

\section{Lung function tests}

Before LT, significant disorders of ventilatory efficiency were recorded in all study participants (FVC $=39.4 \pm$ $13.6 \%$ pred., $\mathrm{FEV}_{1}=33.1 \pm 15.6 \%$ pred.). After the operations, the VC capacity observed had increased by twice as much as before the operations $(1.64 \pm 0.68 \mathrm{~L}$ vs. $2.88 \pm 0.77 \mathrm{~L}$, $p<0.05)$. The value of $\mathrm{FEV}_{1}$ increased from an average of $1.37 \pm 0.81 \mathrm{~L}$ to $2.09 \pm 0.59 \mathrm{~L}(p<0.05)$. The largest increase in spirometric test values was noticed in patients with COPD (FVC\%pred.: 36.2 vs. $74.09 \%$ ). 


\section{Dyspnea analysis}

Before the transplantation, the examined patients reported significant dyspnea in all estimated scales. In the MRC questionnaire before the transplantation, one patient reported maximum dyspnea (dyspnea appeared while dressing and during other daily activities) and $10 \mathrm{pa}-$ tients reported submaximal dyspnea (they were not able to walk a 90-m distance). After the LT, patients presented a significant improvement in the assessed dyspnea on the MRC scale $(3.55 \pm 0.69$ vs. $1.55 \pm 1.0, p=0.001)$. The greatest improvement was in patients with COPD (2.33 points) and the lowest in those with IPF (1.78 points). In both of these groups, the improvement was statistically significant $(p<0.05)$.

A statistically significant improvement was also seen in the assessment of dyspnea by the BDI test. It was particularly visible in summary results of $B D I(F I+M T+M E)$, where we reported a statistically significant $(p=0.001)$ improvement $(1.70 \pm 1.53$ vs. $7.9 \pm 2.83)$. Before the transplantation, each domain of the BDI test showed significant dyspnea in all patients, and their averages were not higher than 1.0. The largest deficiency before the transplantation was seen in the $\mathrm{Fl}$ domain. The average in the examined group was $0.31 \pm 0.60$, which increased to $2.50 \pm 1.21$ $(p=0.001)$ after the transplantation. The largest increase was seen in patients with COPD, especially in the MT and ME domains (2.8 points and 3.25 points, respectively). The smallest increase was seen in the MT domain (1.6 point) in patients with ILD.

\section{Quality of life}

Before the transplantation, patients assessed their quality of life as low in all domains of the SF-36 questionnaire. The PCS before the transplantation was $25.4 \pm 8.3$ and the MCS was $39.5 \pm 8.5$ (Table III).

The biggest impairments the patients observed were in physical functioning (PF; $15.1 \pm 11.1$ ), limitations caused by physical health (RP; $20.5 \pm 24.7)$, general health $(\mathrm{GH}$; $25.3 \pm 10.6$ ), and limitations caused by mental health (RE; $23.6 \pm 24.8$ ) (Table III). After the lung transplantation, the only decrease in score observed in the domains assessing the quality of life was in bodily pain (BP, $53.1 \pm 30.5$ vs. $50.2 \pm 12.0$ ). Improvements were seen in all other domains of the SF-36 questionnaire. The biggest improvements were observed in the following domains: $P F(15.1 \pm 11.1$ vs. $45.0 \pm 10.6), \operatorname{RP}(20.5 \pm 24.7$ vs. $42.1 \pm 11.7)$, and RE $(23.6 \pm$ 24.8 vs. $44.4 \pm 15.8)$. After lung transplantation, the total assessment of physical health (PCS) in the study group grew to $45.0 \pm 9.6$ and the total assessment of mental health (MCS) grew to $50.3 \pm 11.4$. By and large, the biggest increase in each domain of the SF-36 questionnaire was noted in the patient group with IPF (171 points). In this group, the biggest improvement was observed in PF (PF; + 31.9 points). The lowest overall improvement was observed in the patient group with ILD (98 points). The decrease in the scores for pain assessment (BP; -18.9) influenced this outcome.

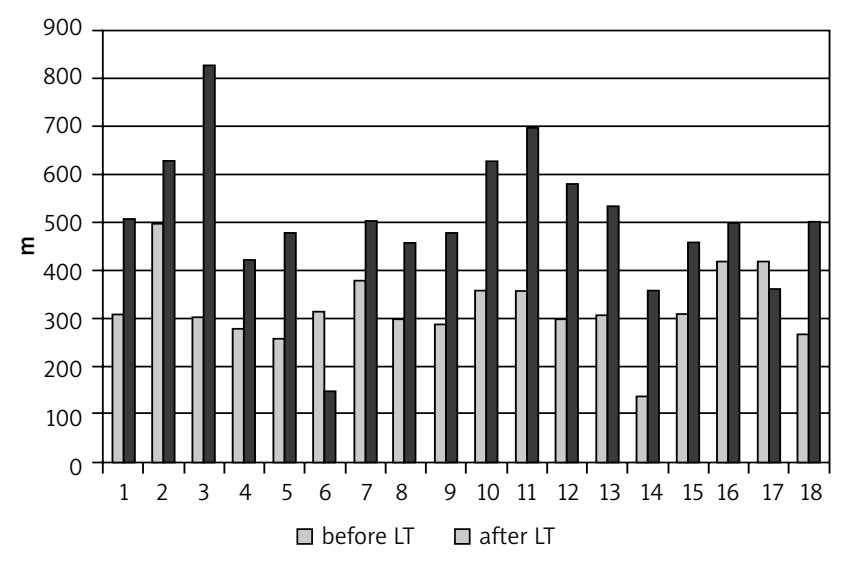

Fig. 1. Results of the 6MWT for each patient before and after LT

\section{Discussion}

The present study presents the two-year outcome of lung transplantations performed at the Silesian Center for Heart Diseases in Zabrze in the years 2004-2009. This period covers the first years of the introduction of the Lung Transplantation Program in Poland. Patients who were qualified for LT in other medical centers were not included in the study, particularly the patients with primary lung hypertension and cystic fibrosis. The program for cystic fibrosis patients was introduced in 2010. In our study, 66\% of the patients survived the period of two years after the transplantation. In comparison to Nathan's findings [5], we consider this a very good result, considering that the analyzed period includes the introduction of Poland's Lung Transplantation Program. The team of pulmonologists participating in qualifying patients for lung transplantation considers a very careful evaluation of patients an important factor helping to avoid the qualification of patients from a high-risk group for transplantation. Disqualifying patients in high-risk groups is a standard protocol whenever new therapeutic methods are introduced into the clinical practice. For example, the characteristics of high-risk patients for LT include: age over 65 years, chronic mechanical ventilation, and symptomatic osteoporosis [5]. In the presented material, the single lung transplantation dominated (SLTs, 80\%). The Silesian Center for Heart Diseases in Poland started with SLTs, and is currently performing double lung transplantations (DLTs) as well.

The 6MWT is commonly accepted as an objective tool to estimate the physical effort ability in patients with cardiovascular diseases $[3,6]$. The $6 \mathrm{MWT}$ distance achieved is an independent factor of survival chances for patients waiting for transplantation [7]. Tuppin et al. reported that patients who are not able to walk a $315-\mathrm{m}$ distance have a higher risk of death, regardless of other factors such as age, weight, BMI, ejection fraction of the left ventricle of the heart, oxygen partial pressure in the blood, and the waiting time for transplantation [8]. In the studied group, the distance achieved in the 6MWT before the transplantation came to an average of $312.95 \mathrm{~m}$. These were patients with reduced cardiovascular and general physical efficiency. 
After the transplantation, the average distance in the 6MWT test increased by almost $200 \mathrm{~m}$, reaching the value of $505.8 \mathrm{~m}$. Gerbase et al. assessed patients after LT over a 7-year observation period [9]. In their study, the average distance achieved in the 6MWT was $429 \mathrm{~m}$ one year after LT, and $433 \mathrm{~m} 3$ years after. The increase in the distance achieved in the 6MWT was used by the authors as a basic parameter estimating the effectiveness of the performed operations, and is often assumed as a point of reference for other parameters such as physical activity and the quality of life [7-10]. The authors state that, even though one study patient displayed a statistically significant increase in the post-transplant achieved distance, it is rare that patients are able to cover a normal distance in the 6MWT after lung transplantation. This occurrence is explained by Bartels et al. [11], who reported the outcomes of the quality of life, respiratory function, and ergospirometric tests carried out on 153 patients over a 7-year observation period after lung transplantation. The authors showed that, despite an increase in ventilatory efficiency, the physical effort ability assessed by the ergospirometric tests in their study patients was significantly reduced and did not exceed $50 \%$ pred. According to the authors, it is a consequence of distal muscle injury as a result of the supplied immunosuppression, muscle atrophy, and sustaining dyspnea rather than dysfunctions of the cardiovascular system. In our study, we observed similar circumstances. We observed a significant improvement of spirometric values and a significant improvement in the 6MWT results, although the patients' reported dyspnea levels varied.

Lung transplantation is performed to prolong life and improve the quality of life in patients with irreversible lung injury in cases where pharmacological therapy does not bring improvement [5]. In the last years, a number of tools have been developed to estimate the quality of life in functional, psychological, and social aspects [12]. The questionnaire most often used to assess the quality of life is the SF-36 questionnaire. A comparative analysis of the outcomes of the SF-36 in our studied group with the assessments of the quality of life reported in the literature showed that patients similarly assessed Physical Functioning, Role Physical, General Health, and Vitality as worse before lung transplantation than after $[13,14]$. This assessment was lower in the group of patients waiting for LT in comparison with patients waiting for kidney, liver, or bone marrow transplantations. It is believed that a low assessment of the quality of life in the Physical Functioning, Role Physical, General Health, and Vitality domains results from problems related to breathing and perceived dyspnea [15]. In these domains, the biggest improvement was observed. Similarly, in the assessed group of patients, an improvement of around 20 points was observed after transplantation in the domains of Role Physical, General Health, and Vitality after lung transplantation, and an improvement of 30 points was observed in the domain of Physical Functioning, which is not only statistically significant, but also defined as a clinical improvement in the SF-36 assessment manual [15]. Similar to other studies, the patients in our study group assessed their mental (psychical) health and pain ailments connected with the disease with the highest scores. In these domains, we observed, as did other authors $[13,14]$, the smallest improvement after the transplantation. In the domain of Bodily Pain, patients reported a deterioration after the transplantation. This aspect is important, as it was carried out two years after the transplantation and it should not be connected with the surgery. It is supposed that the experienced pain is connected with immunosuppression, which has many side effects, such as osteoporosis. Assessing the general perception of the quality of life in the estimated group after the transplantation, we conclude that, in comparison with the data presented by other authors, the quality of life is lower $[9,10,13,14]$. The value did not exceed 55 points in any of the domains of the SF-36 questionnaire taken after the transplantation, while in such domains as Social Functioning and Emotional State, other authors observed values over 80 points. Perhaps patients in Poland are exposed to greater stress and suffering, which results in a lower assessment of their quality of life. The study showed that the majority of patients had a survival rate of more than 2 years and an improvement of the general and ventilatory ability. The obtained data do not differ from the results presented in other centers. Based on these positive results, we find that Poland's current number of lung transplantations, 15 per year in a population of 37 million residents, is insufficient. We conclude that it is necessary to develop and expand the lung transplantation program in Poland.

\section{Disclosure}

Authors report no conflicts of interest.

\section{References}

1. Jastrzębski D, Czyżewski D, Ziora D, Zakliczyński M, Wojarski J, Nowak J, Przybylski R, Zembala M, Kozielski J. Single lung transplant - one year follow-up [in Polish]. Pneumonol Alergol Pol 2004; 9-10: 424-428.

2. Jastrzębski D, Kozielski J, Banas A, et al. Quality of life during one-year observation of patients with idiopathic pulmonary fibrosis awaiting lung transplantation. J Physiol Pharmacol 2005; 56 (Suppl.4): 99-106.

3. Crapo RO, Casaburi R, Coates AL, Enright PL, Maclntyre NR, McKay RT, Johnson D, Wanger JS, Zeballos RJ, Bittner V, Mottram C. ATS Statement: Guidelines for the Six-Minute Walk Test. Am J Respir Crit Care Med 2002; 166: 111-117.

4. Quanjer PH, Tammeling GJ, Cotes JE, Pedersen OF, Peslin R, Yernault JC. Lung volumes and forced ventilatory flows. Report Working Party Standardization of Lung Function Tests, European Community for Steel and Coal. Official statement of the European Respiratory Society. Eur Respir J Suppl 1993; 16: 5-40.

5. Nathan SD. Lung transplantation. disease-specific consideration for referral. Chest 2005; 127: 1006-1016.

6. Salzman SH. The 6-min walk test: clinical and research role, technique, coding, and reimbursement. Chest 2009; 135: 1345-1352.

7. Martinu T, Babyak M, O'Conneil CF, Carney RM, Trulock EP, Davis RD, Blumenthal JA, Palmer SM; INSPIRE Investigators. Baseline 6-min walk distance predicts survival in lung transplant candidates. Am J Transpl 2008; 8: 1498-1505.

8. Tuppin MP, Paratz JD, Chang AT, Seale HE, Walsh JR, Kermeeen FD, McNeil KD, Hopkins PM. Predictive utility of the 6-minute walk distance on survival in patients awaiting lung transplantation. J Heart Lung Transplant 2008; 27: 729-734. 
9. Gerbase MW, Spiliopoulos A, Rochat T, Archinard M, Nicod LP. Health-related quality of life following single or bilateral lung transplantation. A 7-year comparison to functional outcome. Chest 2005; 128: 1371-1378.

10. Langer D, Gosselink R, Pitta F, Burtin C, Verleden G, Dupont L, Decramer M, Troosters T. Physical activity in daily life 1 year after lung transplantation. J Heart Lung Transplant 2009; 28: 572-578.

11. Bartels MN, Armstrong HF, Gerardo RE, Layton AM, Emmert-Aronson BO, Sonett JR, Arcasoy SM. Evaluation of pulmonary function and exercise performance by cardiopulmonary exercise testing before and after lung transplantation. Chest 2011; 140: 1604-1611.

12. Yusen RD. Technology and outcomes assessment in lung transplantation. Proc Am Thorac Soc 2009; 6: 128-136.
13. Goetzmann L, Klaghofer R, Wagner-Huber R, Halter J, Boehler A, Muellhaupt B, Schanz U, Buddeberg C. Quality of life and psychosocial situation before and after lung, liver or an allogeneic bone marrow transplant. Swiss Med Wkly 2006; 136: 281-290.

14. Goetzman L, Sarac N, Ambuhl P, Boehler A, Irani S, Muellhaupt B, Noll G, Schleuniger M, Schwegler K, Buddeberg C, Klaghofer R. Psychological response and quality of life after transplantation: a comparison between heart, lung, liver and kidney recipients. Swiss Med Wkly 2008; 138: 477-483.

15. Ware J, Kosinski M, Gandek B, et al. SF-36 health survey. Manual and interpretation guide. QualityMetric Incorporated, Lincoln, 2004. 